\begin{tabular}{|l|l|l||}
\hline \multicolumn{2}{|c|}{ PublisherInfo } \\
\hline \hline PublisherName & $:$ & BioMed Central \\
\hline \hline PublisherLocation & $:$ & London \\
\hline \hline PublisherImprintName & $:$ & BioMed Central \\
\hline \hline
\end{tabular}

\title{
E. coliages
}

\begin{tabular}{|l|l|l||}
\hline \multicolumn{2}{|c|}{ ArticleInfo } \\
\hline \hline ArticleID & $:$ & 5057 \\
\hline \hline ArticleDOI & $:$ & $10.1186 /$ gb-spotlight-20050204-02 \\
\hline \hline ArticleCitationID & $:$ & spotlight-20050204-02 \\
\hline \hline ArticleSequenceNumber & $:$ & 33 \\
\hline \hline ArticleCategory & $:$ & Research news \\
\hline ArticleFirstPage & $:$ & 1 \\
\hline \hline ArticleLastPage & $:$ & 3 \\
\hline \hline & & RegistrationDate : 2005-2-4 \\
\hline ArticleHistory & $:$ & OnlineDate \\
\hline \hline ArticleCopyright & $:$ & BioMed Central Ltd2005-2-4 \\
\hline \hline ArticleGrants & $:$ & \\
\hline \hline ArticleContext & $:$ & 130596611 \\
\hline \hline
\end{tabular}


The bacterium Escherichia coli, previously considered not susceptible to aging, and thus functionally immortal, does experience aging and death, researchers report in February's PLoS Biology.

"Until recently, people thought that bacteria cannot age," said Martin Ackermann, of the ETH Zentrum, who was not involved in the study. "Then, we published this paper showing aging in bacteria with asymmetric division. The next question was if a visible morphological asymmetry was necessary or whether all bacteria could age. This new paper suggests that aging can actually be found in all bacterial cells, maybe in all living cells."

In the PLoS study, Eric Stewart, of INSERM and Paris 5 René Descartes University, and his colleagues used automated time-lapse microscopy to follow individual bacteria throughout nine subsequent cycles of reproduction and measured several physical parameters in over 35,000 cells. They found that daughter cells that inherited the "old pole" of a dividing parent cell - a pole coming from the previous generation in contrast to one newly formed - had a reduced rate of growth, a reduced rate of offspring formation, and an increased risk of dying, compared to cells inheriting new poles.

The team also discovered that although division in E. coli does not show morphological asymmetries, it is characterized by functional asymmetries, which has not been described in this species before. That could be how the organism satisfies one of the requirements of the established hypothesis of aging: only organisms that undergo asymmetric division, and produce offspring that are smaller than the parents and thus need to grow and develop before reproducing themselves, can age. E. coli, however, does not have smaller offspring, nor does it undergo a juvenile phase.

Thomas Nyström, of Göteborg University, acknowledged that the paper casts some doubt on the idea that $E$. coli divides in a perfectly symmetrical fashion so that the daughter cells display equal fitness. "However, it appears a bit early to announce that $E$. coli belongs to organisms exhibiting mandatory replicative aging and that immortality is too costly or mechanistically impossible in natural organisms, as the authors state in the discussion," Nyström told The Scientistin an E-mail.

Nyström was most impressed by the fact that the authors were able to measure differences in generation times of about 30 seconds with a standard error of only 1.7 seconds. "As far as I know, generation times have never before been measured with such accuracy," Nyström said. "The method used may be instrumental in analyzing potential fitness mutants that show alterations in generation times that are too subtle to analyze."

"This type of experiment has been attempted before," said Stewart, "but what allowed us to do this was automation. Custom software designed for this experiment allowed us to analyze the images all through the computer. We also expressed a fluorescent protein in the cells, which made the imaging easier, and gave us better resolution."

The authors suggest that $E$. coli could provide candidate genes that researchers can look for in higher organisms. Homologues of bacterial Mut mismatch repair proteins have been implicated in aging in humans, although Mut has not been linked to aging in bacteria. 
"Molecular mechanisms might be very different between bacteria and, for example, humans, because bacteria don't have mitochondria or telomeres, two things that have been speculated to be involved in aging," Ackermann said.

E. coli may now be a good model for studying aging, according to Daniel Promislowof the University of Georgia.

\section{References}

1. E.J. Stewart et al., "Aging and death in an organism that reproduces by morphologically symmetric division," PLoS Biol, 3:e45, February 1, 2005., [http://www.plosbiology.org/plosonline/?request=getdocument\&doi=10.1371\%2Fjournal.pbio.0030045]

2. Martin Ackermann, [http://www.eco.ethz.ch/portraits/ackermann/]

3. M. Ackermann et al., "Senescence in a bacterium with asymmetric division," Science, 300:1920, June 20,2003

4. Eric Stewart, [http://www.necker.fr/tamara/pages/eric.html]

5. Thomas Nyström, [http://www.gmm.gu.se/groups/nystrom/]

6. Daniel E.L. Promislow, [http://www.genetics.uga.edu/faculty/bioPromislow.html] 